\title{
AGRO-ECONOMIC POTENTIAL OF CAPSICUM WITH DRIP IRRIGATION AND MULCHING
}

\author{
V. K. Choudhary ${ }^{1}$ and M. C. Bhambri \\ Department of Agronomy, Indira Gandhi Krishi Vishwavidyalaya, Chhattisgarh, India
}

\begin{abstract}
ABSTARCT
A field experiment was conducted during 2006-07 and 2007-08 at Precision Farming Development Centre, Indira Gandhi Agricultural University, Raipur, Chhattisgarh, India, to evaluate the production, potential and economics of capsicum (Capsicum annum L.) as influenced by drip irrigation and mulches. Experiment was laid out in a split-plot design replicated thrice with irrigation levels 1.0 Epan (Pan evaporation) through drip, 0.8 Epan through drip, 0.6 Epan through drip and 1.0 Epan with flood irrigation (FI) in main plot and mulches (i.e. no mulch (Glyphosate @ $6.0 \mathrm{ml} \mathrm{I}^{-1}$ followed by 2 hand weedings), black polythene mulch (BPM: $40 \mu$ thickness), transparent polythene mulch (TPM: $40 \mu$ thickness), paddy straw mulch (PSM: $5 \mathrm{t} \mathrm{ha}^{-1}$ ) in sub plots. The growth parameters like plant height, number of primary and secondary branches, stem girth, leaf area, leaf area index, dry weight of leaf, stem, fruit and total dry weight were maximum with drip irrigation at 1.0 Epan followed by drip irrigation at 0.8 Epan. Among the mulches the maximum values of the growth parameters were noticed with black polythene mulch followed by paddy straw mulch. The yield attributes like fruit length, fruit volume, fruit girth, per cent fruit set, fruits/plant, green capsicum fruit weight and yields were higher with drip irrigation at 1.0 Epan followed by drip at 0.8 Epan.

Among the mulches, all the yield attributes were found higher with black polythene mulch followed by paddy straw mulch; whereas least yield attributes were measured with no mulch. Marginal cost, marginal return, MR: MC, cost of cultivation, net returns and $\mathrm{B}: \mathrm{C}$ were higher with drip irrigation at 1.0 Epan followed by drip irrigation at 0.8 Epan. Among different mulches all the economic parameters were higher with black polythene mulch followed by paddy straw mulch except MR: MC and B: C ratio. Capsicum with paddy straw mulch produced higher values of MR: $M C$ and $B$ : $C$ ratios.
\end{abstract}

Key words: Capsicum, drip irrigation, economics, growth, mulches, yield

\footnotetext{
${ }^{1}$ Corresponding author email: ind_vc@rediffmail.com
}

Received: 11.03.2012 
V. K. Choudhary and M. C. Bhambri

\section{INTRODUCTION}

Capsicum is one of the important vegetable crops in India. It is not only used as vegetable but also it occupies a maximum place in kitchen. Its importance is increasing gradually in industries. Due to high content of capsaicin, this ingredient is extracted from capsicum for flavour purpose. Growing capsicum in field condition is very difficult because it is much sensitive to both insufficient and excess supply of water; which is not suitable for capsicum cultivation. The crop is generally grown during post rainy season so that management of water becomes convenient. Green capsicum plants are more susceptible to water logging, flood water should be drained out from the field as early as possible; otherwise plants might die. In these condition furrow and drip irrigation are recommended whereas, sprinkler irrigation causes disease development and spread (Berke et al., 1999). Therefore, scheduling of irrigation and application of water as per the requirement is very much important (Campbell and Turner, 1990). Optimum quantity of water must be applied during the different crop growth periods to get higher capsicum yield. It is very much required to determine the water consumption of plants and periods that plants are susceptible for water beside the irrigation intervals in order to increase the crop yield (Ertek et al., 2007). During post rainy season temperature comes down which affect the growth and development of capsicum. In this condition placement of mulch play a vital role in order to maintain the temperature and moisture content (Patel et al., 2009). Keeping all this the present study was carried out to evaluate the production potential and economics of capsicum with drip irrigation and mulches under Chhattisgarh plain.

\section{MATERIALS AND METHODS}

A field study was conducted at Precision Farming Development Centre, Indira Gandhi Agricultural University, Raipur (India) during 2006-07 and 2007-08. The place receives an average annual rainfall of 1200-1400 mm most of which (about 85 per cent) is received from third week of June to mid September and scanty during October and February. The soil samples were taken from $20 \mathrm{~cm}$ soil depths and a composite sample was drawn for analysis. The soil was silty clay loam, neutral in reaction ( $\mathrm{pH} 7.06$ ), medium in organic carbon (0.49 per cent), low in nitrogen (236.5 $\mathrm{kg} \mathrm{ha}^{-1}$ ), medium in phosphorus (18.8 $\mathrm{kg} \mathrm{ha}^{-1}$ ), high in available potassium (310.5 kg $\mathrm{h}^{-1} \mathrm{a}$ ) and normal in EC $\left(0.42 \mathrm{dS} \mathrm{m}^{-1}\right.$ at $\left.25^{\circ} \mathrm{C}\right)$. Capsicum (cv. Agnirekha) was taken as test crop during study. The experiment was laid out in a split plot design with three replications, Main plots were allotted for irrigation levels [i.e. 1.0 Epan (Pan evaporation) through drip, 0.8 Epan through drip, 0.6 Epan through drip and 1.0 Epan with flood irrigation (FI)] and sub plots were treated with mulches [i.e. no mulch (glyphosate @6.0 ml l-1 followed by 2 hand weeding), black polythene mulch (BPM; $40 \mu$ thickness), transparent polythene mulch (TPM; $40 \mu$ thickness), paddy straw mulch (PSM; $5 \mathrm{t} \mathrm{ha}^{-1}$ )]. Planting spacing was maintained as per recommended spacing of $60 \mathrm{~cm} \times 45 \mathrm{~cm}$. All other cultural practices were done as per standard recommendation for capsicum. 
Seedlings were raised in a nursery and after preparing the main field, five week old seedlings were transplanted. Drip laterals were placed at $8^{\text {th }}$ days after transplanting (DAT) and started imposing the allotted treatments from 10 DAT. Mulches were placed on bed carefully at 12 DAT. During investigation growth parameters, yield attributes, yields were observed and economics were calculated as per existing market rate. Followings are the important parameters which were considered for economic analysis;

1. Yield difference $\left(\mathrm{t} h \mathrm{~h}^{-1}\right)=$ Yield of treated practice- yield of conventional practice

2. Marginal returns (MR) $\left(\mathrm{Rs} \mathrm{ha}^{-1}\right)=$ Additional yield over flood irrigation $\left(\mathrm{t} \mathrm{ha}^{-1}\right)$ $\mathrm{x}$ price of produce $\left(\mathrm{Rs} \mathrm{t}^{-1}\right)$

3. Marginal cost $(\mathrm{MC})\left(\mathrm{Rs} \mathrm{ha}^{-1}\right)=$ Additional yield $\left(\mathrm{t} \mathrm{ha}^{-1}\right) \mathrm{x}$ cost to produce unit quantity $\left(\mathrm{Rs} \mathrm{t}^{-1}\right)$

Statistical analysis was done for all parameters by adopting the procedures of Gomez and Gomez (1984).

\section{RESULTS AND DISCUSSION}

\section{Effect of drip irrigation}

\section{Growth parameters}

Drip irrigation at 1.0 Epan produced maximum plant height $(63.18 \mathrm{~cm})$, number of primary (9.30) and secondary branches/plant (14.13), stem girth (2.13 $\mathrm{cm}$ ), dry matter accumulation (g plant ${ }^{-1}$ ) on different plant parts (viz, leaves (7.57), stem (17.29), fruit (21.32) and their total weight (45.92), leaf area $\left(81.95 \mathrm{dm}^{2}\right)$ and leaf area index (3.04) but was statistically at par with drip irrigation at 0.8 Epan (Table 1). Moisture content was found sufficient for these treatments throughout the crop growth which provided conducive environmental condition. With, drip irrigation levels, a small portion of soil volume were irrigated, which reduced the evaporation loss and eliminated runoff. The loss of water was low due to slow flow rate and better canopy coverage. All the growth parameters are having prime importance for better availability of solar radiation and responsible to produce higher photosynthates (Doyle et al., 1994 and Bandi, 1994). Whereas, flood irrigation at 1.0 Epan recorded lower growth parameters followed by drip irrigation at 0.6 Epan.

\section{Yield and yield attributes}

The yield attributes like fruit length $(12.90 \mathrm{~cm})$, fruit volume $(28.44 \mathrm{cc})$, fruit girth (6.43, 5.70 and $3.78 \mathrm{~cm}$ at top middle and bottom respectively), per cent fruit set (66.38), fruit/plant (32.35), green fruit weight (24.54 $\mathrm{g} \mathrm{fruit}^{-1}$ ) and capsicum yield (32.02 $\mathrm{t} \mathrm{ha}^{-1}$ ) were higher with drip irrigation at 1.0 Epan followed by drip at 0.8 Epan (Table 2). This was due to availability of soil moisture in sufficient range which possibly led to positive effect on growth parameters, enhanced the photosynthetic 
area and better partitioning of dry matter produced and finally, resulted in more number of flowers and less flower dropping. Therefore, fruit setting was more and the yield was maximum. However, with flood irrigation at 1.0 Epan, the crop plants suffered from adverse conditions like excess and limited moisture supply respectively at the beginning and end of the irrigation cycles respectively which enhanced the possibility of flower dropping and finally reduced capsicum yield. Similar findings were also reported by Hegde and Srinivas, 1989 in tomato and Bandi, 1994 in green chilli.

\section{Economics}

Drip irrigation at 1.0 Epan had the highest cost of cultivation (Rs 67,302 ha-1), net return (Rs 2,52,898 ha-1) and B: C (3.76) followed by drip irrigation at 0.8 Epan (Table 3). However, flood irrigation at 1.0 Epan gave the lowest values of economic parameters. This is due to higher yield recorded on drip irrigation at 1.0 Epan. Higher levels of drip helped the plants for better production of dry matter due to availability of moisture in root vicinity, which helped the plant to induce the floral buds and finally contributed to higher per cent of fruit set and yield (Palada et al., 2001). Yield difference (11.50 tha $\mathrm{th}^{-1}$ ), MC (Rs 11,500 ha-1) and MR (Rs 24,172 ha-1) and MR: MC ratio (4.76) measured higher with drip irrigation at 1.0 Epan followed by drip irrigation at 0.8 Epan (Table 4). However, with drip irrigation at 0.6 Epan registered lower values of above mentioned parameters over flood irrigation at 1.0 Epan. These are due to higher yield of capsicum and comparatively lower investment per unit of production on drip irrigated plots.

\section{Effect of mulching \\ Growth parameters}

All the growth parameters were maximum with black polythene mulch followed by paddy straw mulch. However, lower values of all the growth parameters were obtained with no mulch followed by transparent polythene mulch (Table 1). The increase in dry matter production/plant (45.45 $\left.\mathrm{g} \mathrm{plant}^{-1}\right)$ and its accumulation in leaf (7.43 g/plant) stem (16.94 $\mathrm{g}$ plant $\left.^{-1}\right)$ and fruits (21.19 $\left.\mathrm{g} \mathrm{plant}^{-1}\right)$ were influenced by favourable growth in terms of maximum plant height $(63.11 \mathrm{~cm})$ and number of primary (9.41) and secondary branches/plant (13.95). The higher dry matter production might be due to higher leaf area $\left(82.52 \mathrm{dm}^{2}\right)$ and leaf area index (3.06). The prerequisite for high yield is the maximum dry matter production/plant coupled with higher photosynthetic rate for building of organic substances in the plant (Choudhary et al., 2006). Sudha (1999) reported that highest dry matter accumulation, leaf area and leaf area index in tomato plant were found by black plastic mulching compared to the other mulch.

\section{Yield and yield attributes}

Placement of black polythene mulch produced highest fruit yield of capsicum (31.24 t ha ${ }^{-1}$ ), which was 6.25, 26.12 and 28.48 per cent higher than paddy straw, 
transparent polythene mulch and no mulch respectively. The higher capsicum fruit yield obtained from both black polythene and paddy straw mulches may be attributed to the increased values in yield components viz. fruit length $(12.71$ and $12.34 \mathrm{~cm}$ respectively), fruit volume (27.37 and 26.80 cc respectively), average fruit girth (5.34 and $5.01 \mathrm{~cm}$ respectively), per cent fruit set (67.16 and 64.24 respectively), number of fruits/plant (31.56 and 28.70 respectively), fruit weight (25.88 and 24.25 g fruit $^{-1}$ respectively). Vos and Sumarni (1997) also reported increased number of fruits, fruit weight/plant and fruit size by polythene and organic mulch. Maximum number of fruits/plant (31.56) was found in the present investigation with black polythene mulch, which was 9.96, 37.22 and 51.15 per cent higher than paddy straw, transparent polythene and no mulch, respectively. It might be due to higher total dry matter accumulation and proper translocation of food materials to the fruits, these helped to the formation of more flowers, less flower and fruit dropping as well as better uptake of nutrient and moisture due to favourable conditions created by mulching (Hegde and Srinivas, 1989).

\section{Economics}

The total cost of cultivation was high with black polythene mulch (Rs 73,796 $\mathrm{ha}^{-1}$ ) and this was comparable to transparent polythene mulch (Rs 73,361 ha ${ }^{-1}$ ). No mulch treatment had lowest cost of cultivation (Rs 56,153 ha ${ }^{-1}$ ) followed by paddy straw mulching (Rs 58,252 ha ${ }^{-1}$ ). Gross (Rs 3,12,400 ha-1) and net income (Rs 2,38,604 $\mathrm{ha}^{-1}$ ) were maximum with black polythene mulch but at par with paddy straw mulch (Rs 2,94,000 and 2,35,748 $\mathrm{ha}^{-1}$ respectively). This might be due to high yield obtained under black polythene mulch. No mulch gave minimum gross (Rs 2,25,700 ha $\left.{ }^{-1}\right)$ and net income $\left(1,69,547 \mathrm{ha}^{-1}\right)$ followed by transparent polythene mulch (Rs 2,47,700 and 1,74,339 $\mathrm{ha}^{-1}$ respectively), due to lower yield of capsicum under these treatments. Lower returns were mainly due to the lowest yield harvested and these findings were in agreement with earlier finding of Patel et al., (2009). Benefit cost ratio did not follow the above mentioned trend and the highest $\mathrm{B}$ : $\mathrm{C}$ was recorded with paddy straw mulch (4.05). This was due to the high capsicum yield accompanied with low cost of cultivation. There was no significant difference between black polythene mulch and no mulch. However, lowest B: C ratio (2.38) was obtained with transparent polythene mulch as compared to other mulches. It was due to lowest capsicum yield and high cost of cultivation involved per unit of production with this treatment.

Fruit yield difference, MC and MR were higher with black polythene mulch (8.67 $\mathrm{t} \mathrm{ha}^{-1}, 86,700$ and 20,481 $\mathrm{Rs} \mathrm{ha}^{-1}$, respectively) followed by paddy straw mulch (Table 4), whereas, MR: MC ratio was higher with paddy straw mulch (5.05) followed by black polythene mulch (4.23). However, transparent polythene mulch recorded the lower values of above mentioned parameters over no mulch. These are due to higher yield of capsicum and relatively lower investment per unit of production on black polythene and paddy straw mulch. 
However, the interaction between drip irrigation levels and mulches were not statistically significant. The finding of the experiment showed that drip irrigation and mulching play a crucial role in the growth, development and finally yield of capsicum. Drip irrigation at 1.0 Epan harvested with higher fruit yield and economic return followed by drip irrigation at 0.8 Epan. Among the mulch materials black polythene mulch harvested with higher yield followed by paddy straw mulch. However, economic returns were registered higher with paddy straw mulch. Therefore, it could be recommended that growers may adopt for drip irrigation at 1.0 Epan with paddy straw mulch in Chhattisgarh plain to obtain higher yield of capsicum with better economic returns.

\section{REFERENCES}

Bandi, A. G. 1994. Influence of irrigation levels and imposition of early moisture stress on growth and yield of green chilli under drip and furrow methods. Ph.D. Thesis, University of Agricultural Sciences, Bangalore.

Berke, T. G., Black, L. L., Green, S. K., Morrish, R. A., Talekar, N. S. and Wang, J. F. 1999. Suggested cultural practices for chili pepper. International cooperators guide. AVRDC publication, pp: 00-483.

Campbell, O. S. and Turner, N. C. 1990. Plant- soil- water relationships. In: Management of farm irrigation systems (Eds. Hoffman G. J., Howell T. A. and Solomon, K. H.) The ASAE., 2950 Niles Road St. Josheph, MI., 15: 49085-49659.

Choudhary, V. K., Ramachandrappa, B. K., Nanjappa, H. V. and Bachkaiya, V. 2006. Yield, economics, quality, sensory evaluation and solar radiation interception as influenced by planting methods and drip irrigation levels in Baby corn (Zea mays L.) vegetable. $J$. Asian Horti., 2(1): 45-48.

Doyle, A., Smittle, W., Lamar Dickens and James, R. 1994. Irrigation regimes affect yield and water use by bell pepper. J. American Soc. Hort. Sci., 119(5): 936-939.

Ertek, A., Sensoy, S., Gedik, I. and Kuciikyumuk, C. 2007. Irrigation scheduling for green capsicum (Capsicum annum L.) grown by field condition by using class A pan evaporation value. American- Eurasian J. Agric. Environ. Sci., 2(4): 349-358.

Gomez, K. A. and Gomez, A. A. 1984. Statistical procedures for agricultural research. John Willey and Sons, New York.

Hegde, D. M. and Srinivas, K. 1989. Studies on irrigation and nitrogen requirements of tomato. Indian J. Agron., 34(2): 157-162.

Palada, M. C., Crossman, S. M. A. and Collingwood, C. D. 2001. Raising vegetable production with micro-irrigation. Inter. Water Irrig., 21: 41-44.

Patel, D. B., Patel, R. H. and Patel, R. B. 2009. Effect of drip irrigation, mulch and nitrogen fertigation on yield and yield attributes of okra (Abelmoschus esculentus). Indian J. Agric. Sci., 79 (1): 12-15.

Sudha, K. N. 1999. Response of rainfed groundnut (Arachis hypogaea L.) to sand mulching and organics in vertic inceptisols. M.Sc. (Agri.) Thesis, University of Agricultural Sciences, Dharwad.

Vos, J. G. M. and Sumarni, N. 1997. Integrated crop management of hot pepper (Capsicum spp.) under tropical low land conditions. Effects of mulch on crop performance and prediction. J. Horti. Sci., 72: 415-424. 
Table 1: Growth parameters as influenced by drip irrigation and mulching in capsicum (pooled data of 2 years)

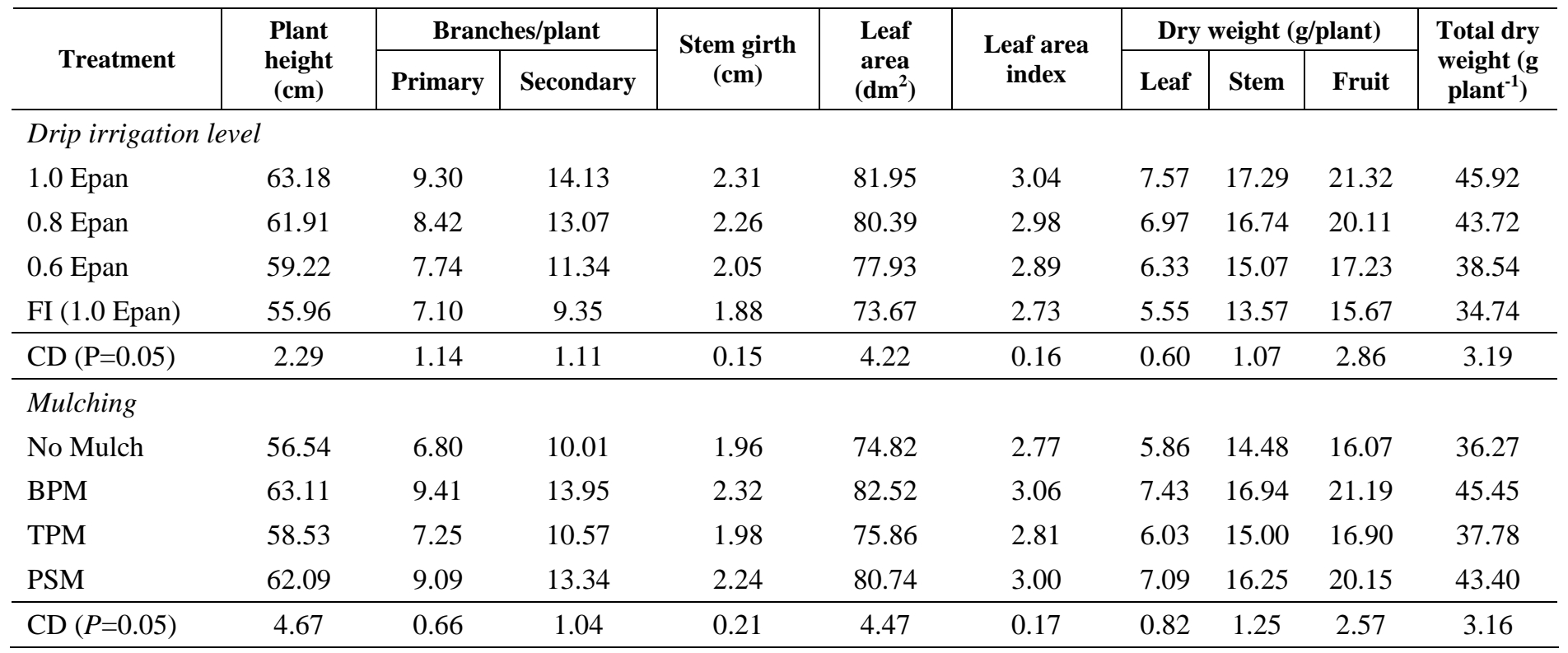

FI, Flood irrigation; BPM, Black polythene mulch; TPM, Transparent polythene mulch; PSM, Paddy straw mulch 
Table 2: Yield attributes and yields as influenced by drip irrigation and mulching in capsicum (pooled data of 2 years)

\begin{tabular}{|c|c|c|c|c|c|c|c|c|c|}
\hline \multirow{2}{*}{ Treatment } & \multirow{2}{*}{$\begin{array}{l}\text { Fruit length } \\
(\mathbf{c m})\end{array}$} & \multirow{2}{*}{$\begin{array}{c}\text { Fruit } \\
\text { volume } \\
\text { (cc) }\end{array}$} & \multicolumn{3}{|c|}{ Fruit girth (cm) } & \multirow{2}{*}{$\begin{array}{c}\text { Fruit set } \\
\quad(\%)\end{array}$} & \multirow{2}{*}{$\begin{array}{l}\text { Fruits/ } \\
\text { plant }\end{array}$} & \multirow{2}{*}{$\begin{array}{l}\text { Fruit weight of green } \\
\text { capsicum (g fruit }^{-1} \text { ) }\end{array}$} & \multirow{2}{*}{$\begin{array}{c}\text { Fruit } \\
\text { yield } \\
\left(\mathrm{t} \mathrm{ha}^{-1}\right)\end{array}$} \\
\hline & & & Top & Middle & Bottom & & & & \\
\hline \multicolumn{10}{|c|}{ Drip irrigation level } \\
\hline 1.0 Epan & 12.90 & 28.44 & 6.43 & 5.70 & 3.78 & 66.38 & 32.35 & 24.54 & 32.02 \\
\hline 0.8 Epan & 12.43 & 27.29 & 6.15 & 5.45 & 3.75 & 65.54 & 30.00 & 22.92 & 29.89 \\
\hline 0.6 Epan & 11.35 & 23.26 & 5.57 & 5.08 & 3.62 & 58.50 & 23.40 & 22.04 & 25.54 \\
\hline FI (1.0 Epan) & 10.06 & 20.12 & 5.13 & 4.60 & 3.20 & 55.60 & 18.38 & 20.29 & 20.51 \\
\hline $\mathrm{CD}(P=0.05)$ & 1.05 & 1.09 & 0.55 & 0.36 & 0.25 & 5.31 & 2.92 & 1.84 & 2.66 \\
\hline \multicolumn{10}{|l|}{ Mulching } \\
\hline No Mulch & 10.56 & 22.27 & 5.28 & 4.88 & 3.28 & 56.29 & 20.88 & 19.25 & 22.56 \\
\hline BPM & 12.71 & 27.37 & 6.48 & 5.67 & 3.88 & 67.16 & 31.56 & 25.88 & 31.24 \\
\hline TPM & 11.11 & 22.66 & 5.52 & 4.91 & 3.49 & 58.32 & 23.00 & 20.42 & 24.77 \\
\hline PSM & 12.34 & 26.80 & 5.99 & 5.36 & 3.70 & 64.24 & 28.70 & 24.25 & 29.40 \\
\hline $\mathrm{CD}(P=0.05)$ & 0.66 & 1.55 & 0.34 & 0.32 & 0.29 & 6.19 & 2.79 & 2.07 & 2.03 \\
\hline
\end{tabular}

FI, Flood irrigation; BPM, Black polythene mulch; TPM, Transparent polythene mulch; PSM, Paddy straw mulch 
Table 3: Cost of cultivation, net returns and B: $\mathrm{C}$ ratio as influenced by drip irrigation and mulching in capsicum (pooled data of 2 years)

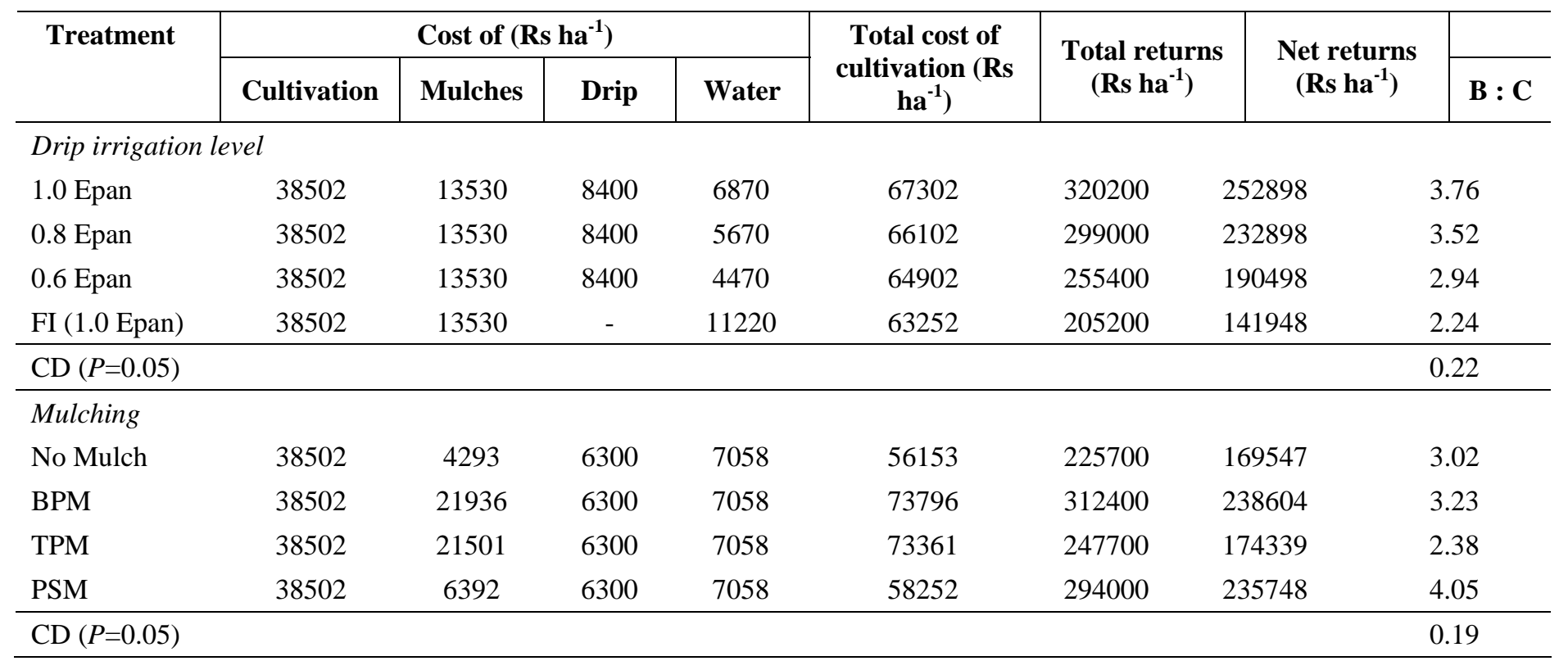

FI, Flood irrigation; BPM, Black polythene mulch; TPM, Transparent polythene mulch; PSM, Paddy straw mulch 
Table 4: Yield difference, marginal return and marginal cost as influenced by drip irrigation and mulching in capsicum (pooled data of 2 years)

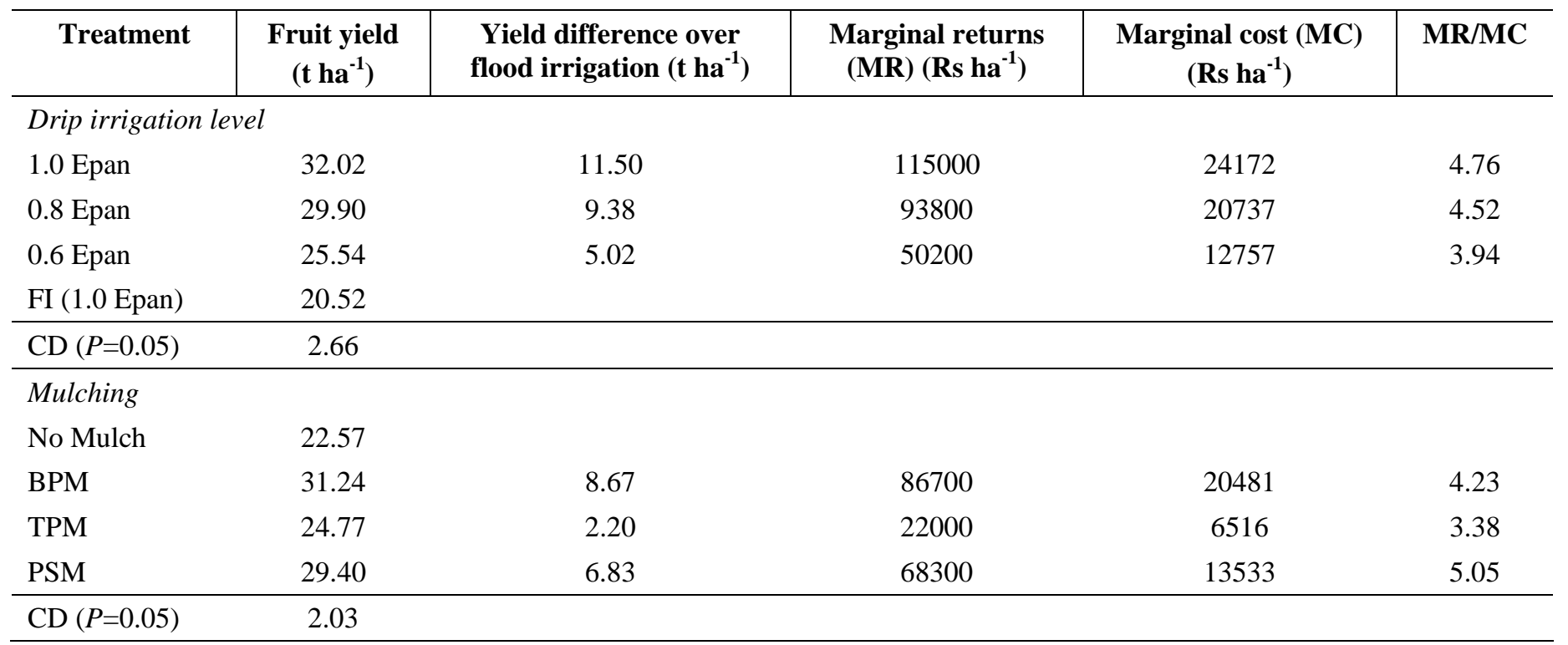

Price of green capsicum, 10/kg, FI, Flood irrigation; BPM, Black polythene mulch; TPM, Transparent polythene mulch; PSM,

Paddy straw mulch 